\title{
An exceptional storm accumulation of nautilids in the Lower Cretaceous of the Neuquén Basin, Argentina
}

\author{
MARCELA CICHOWOLSKI, PABLO J. PAZOS, MAISA A. TUNIK AND MARÍA B. AGUIRRE-URRETA
}

\section{LETHAIA}

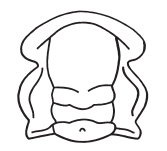

Cichowolski, M., Pazos, P.J., Tunik, M.A. \& Aguirre-Urreta, M.B. 2011: An exceptional
storm accumulation of nautilids in the Lower Cretaceous of the Neuquén Basin, Argen-
tina. Lethaia, DOI: 10.1111/j.1502-3931.2011.00271.x

An exceptional accumulation of nautilid shells of the species Cymatoceras perstriatum (Steuer) is reported and described in the Lower Cretaceous Agrio Formation of the Neuquén Basin (west-central Argentina). The bed represents a storm deposit in a shallowwater environment within the mid-ramp. The evidences of a storm-related origin of the bed come from the petrographic analysis and taphonomic features of the shells, specially the sedimentary infill pattern. The shells are dispersed in patches within the stratum, without any orientation relative to the bedding plane. It is proposed that the shells were floating after the death of the animals, although most of them have an almost complete living chamber. The presence of some heavily encrusted shells suggests that there is a mixing of specimens with different drift times. A variety of factors related to the origin of such high number of nautilid shells are discussed, including a transgressive stand system tract, the possible existence of a gregarious behaviour, changes in salinity and wind directions. $\square$ Lower Cretaceous, Nautilids, Neuquén Basin, shell accumulation, storm deposit.

Marcela Cichowolski [mcicho@gl.fcen.uba.ar], IDEAN, Facultad de Ciencias Exactas y Naturales, Universidad de Buenos Aires, Ciudad Universitaria, Pab. 2, C1428EGA, Buenos Aires, Argentina; Pablo J. Pazos [pazos@gl.fcen.uba.ar], IDEAN, Facultad de Ciencias Exactas y Naturales, Universidad de Buenos Aires, Ciudad Universitaria, Pab. 2, C1428EGA, Buenos Aires, Argentina; Maisa A. Tunik [mtunik@conicet.gov.ar], CONICET, Instituto de Investigación en Paleobiología y Geología, Sede Alto Valle. Universidad Nacional de Río Negro, Isidro Lobo y Belgrano (8332), General Roca, Río Negro, Argentina; María Beatriz Aguirre-Urreta [aguirre@gl.fcen.uba.ar], IDEAN, Departamento de Ciencias Geológicas, Facultad de Ciencias Exactas y Naturales, Universidad de Buenos Aires, Ciudad Universitaria, Pab. 2, C1428EGA, Buenos Aires, Argentina; manuscript received on 27/09/10; manuscript accepted on 26/01/11.
Nautilids are uncommonly documented from postTriassic successions around the world. There is usually only one nautilid representative for each 1000 molluscs seen from other classes (Stenzel in Ladd 1957). Kummel (1956) called attention to the rarity of postTriassic nautilids pointing out that no large collection representing a population had ever been assembled from a single horizon and locality. Post-Triassic nautilids exhibit also very low diversity, existing only a few families and genera (Kummel 1956), and their systematic studies are highly controversial, mainly due to the scarcity of characters to be described and used for classification, and the difficulty to find out synapomorphies that define groups.

Fossil nautilid taphonomy has not been frequently addressed. Especially, nautilid shells accumulations are scarcely known, and the processes that generated them were just slightly described. The reconstruction of the taphonomic history is important because this information improves our understanding of their palaeobiogeography and palaeoecology (Wani 2004). Recently, important contributions about recent Nautilus taphonomy were made by Mapes et al. (2010a, b), whose discussion of present-day species throws light on the taphonomy of fossil shells.

Herein, we report and discuss the taphonomic history and palaeoecology of an exceptional accumulation of nautilid shells, belonging to the species Cymatoceras perstriatum (Steuer). The shell accumulation is found in shallow marine deposits documented in the Lower Cretaceous Agrio Formation that forms part of the marine record of the Neuquén Basin, Argentina. Approximately 200 nautilid shells, representing one of the biggest post-Triassic nautilid concentrations known, were found in a single stratum in the El Salado locality, situated ca. $100 \mathrm{~km}$ south of the Chos Malal city (Fig. 1). Collected specimens are housed at the Palaeontological Collections of the University of Buenos Aires (CPBA), and at the Juan Olsacher Museum in Zapala, Neuquén (PI-MOZ). ES is the abbreviation for El Salado and is the prefix for petrographic samples. 


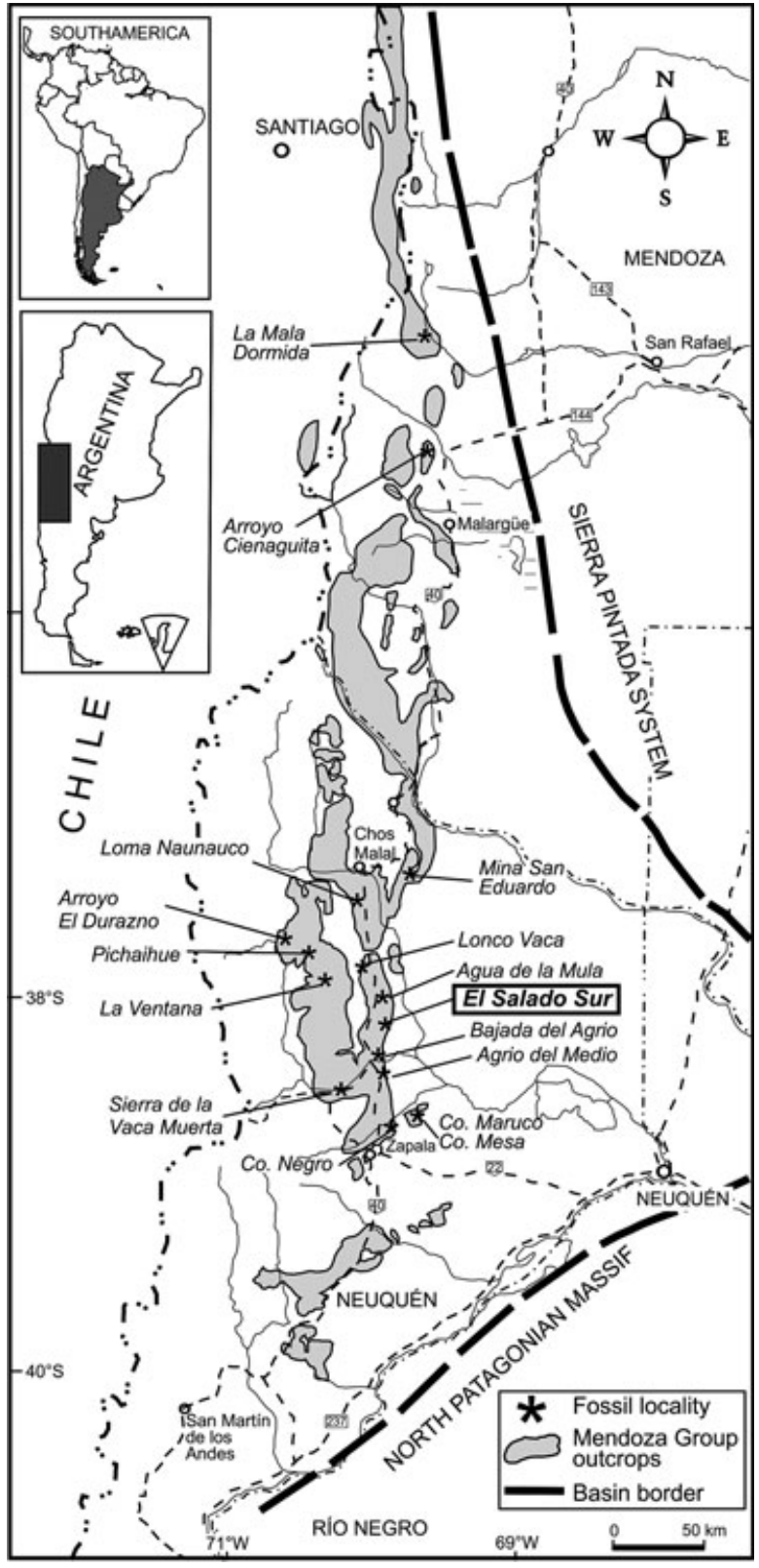

Fig. 1. Detailed map of the Neuquén Basin showing fossil localities, and the position of the El Salado section.

\section{Geological setting and fossil occurrence}

The retro-arc Neuquén Basin in west-central Argentina forms a large embayment located between 35 and $39^{\circ} \mathrm{SL}$ and $69-70^{\circ} \mathrm{WL}$ along the eastern foothills of the Andes (Fig. 1). It is limited to the east and south by extensive cratonic areas, whereas to the west it is bounded by the Andean volcanic arc (Digregorio et al. 1984). The sedimentary succession spanning the latest Jurassic to Early Cretaceous is included in the

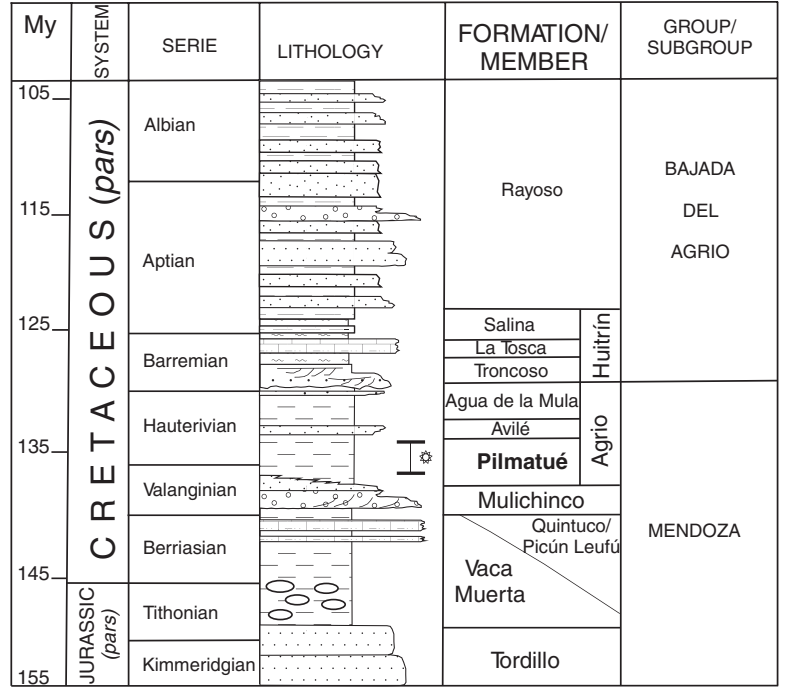

Fig. 2. Stratigraphy of the Lower Cretaceous from the Neuquén Basin. The asterisk indicates the position of the section studied at El Salado Sur.

Mendoza Group (Groeber 1946) (Fig. 2). In Valanginian-Hauterivian times, a transgressive phase culminated with the deposition of the shales, sandstones and limestones of the Agrio Formation, which constitutes a thick marine succession deposited in a storm-dominated shallow marine ramp (Weaver 1931; Legarreta \& Gulisano 1989; Lazo et al. 2005). It has been divided by Leanza et al. (2001) in the Pilmatué, Avilé and Agua de la Mula Members. While the Pilmatué and Agua de la Mula Members comprise marine shales with fossiliferous limestone and sandstone intercalations, most of the latter interpreted as tempestites (Spalletti 1992), the intermediate Avilé Member was deposited during a forced regression and consists mainly of fluvial and aeolian deposits (Veiga et al. 2002).

The general fossil content of the Agrio Formation is composed of ammonoids, bivalves, nautiloids, echinoids, crustaceans, corals, bryozoans, gastropods and rare vertebrates including pycnodontiform fishes and elasmosaurid plesiosaurs. Trace fossils are abundant and diverse and certain groups as tellinacean bivalves and theropod dinosaurs are documented from their traces prior to any body fossil record.

Nautilids are found in the fossiliferous limestones and sandstones of the Agrio Formation, being extremely rare in the shale beds. This facies distribution was interpreted as the result of the relationship between the shell morphology and the biostratinomic pathway followed by shells of ectocochleate cephalopods (Cichowolski \& Aguirre-Urreta 2005).

More than 200 nautilid specimens were collected, and at least 100 more were studied in situ in the 
Agrio Formation during several field trips. All belong to the single species C. perstriatum (Steuer), which is present from Upper Jurassic (Tithonian) to Lower Cretaceous (Hauterivian) beds in west-central Argentina (Cichowolski 2003). Despite the generally low frequency occurrence of this species in the Agrio Formation, there is a strong variability in its abundance in relation to two factors: the locality (i.e. the geographical position within the basin) and the stratigraphic position (based on the ammonoid biostratigraphy of Aguirre-Urreta et al. 2007). The localities where $C$. perstriatum is most abundant are: Agua de la Mula, El Salado Norte/Sur and Bajada del Agrio (Fig. 1), which are rather close to each other, aligned in a S-N direction, and share a quite similar arrangement of lithofacies. Regarding the variability in number of specimens along any stratigraphic section, a very conspicuous peak can be observed in the Early Hauterivian Holcoptychites agrioensis Subzone (Fig. 3). A major abundance in this stratigraphic position was noted in almost all of the localities visited, but that important peak is mostly generated by a great nautilid accumulation in a single bed at El Salado, which was discovered by P.F. Rawson.

In this locality a section of $15 \mathrm{~m}$ thick was logged, corresponding to the middle-upper part of the Pilmatué Member of the Agrio Formation (Figs 2, 4). The nautilid-rich interval is clearly identifiable in the field by orange-coloured limestones, which are particularly common in this interval with respect to other parts of the succession. The logged section comprises a complete record of a coarsening-upwards arrangement that precedes the level rich in nautilids, ending above the first level that records abundant ammonites of the Holcoptychites agrioensis subzone.

\section{Sedimentology and sequence stratigraphy}

\section{Sandy limestones}

They constitute the most abundant carbonate-rich deposits in the studied interval (Fig. 4). Macroscopically they are characterized by an intense orange colour contrasting with the greyish one of most of the siliciclastic deposits. Macroscopically all of them resemble typical limestone beds but microscopically they are classified as mixed beds.

Nautilid bed. - The nautilids documented in this article occur in the uppermost of three amalgamated beds that are up to $70 \mathrm{~cm}$ thick. The bioclastic content increases from the lower to the upper bed. Although the overall thickness remains laterally constant, each bed varies, demonstrating erosional contacts that are not very clear in a close-up view of the beds. The uppermost bed bears the nautilid concentration and it is clearly distinguishable in the field by a very intense orange colour, caused by weathering. Besides nautilids, the top bed contains some ammonite shells (belonging to the species $H$. agrioensis) and randomly disposed articulated bivalves as Steinmanella, Cucullaea and oysters. Both the bivalves as well as the cephalopod phragmocones are empty of sediment but filled with calcitic cement (Figs 5A, 6A-C). There were observed in the top view of the stratum undetermined small fragments of shells grouped in patches, probably conforming gutter casts. Their maximum width is approximately of $10 \mathrm{~cm}$. The bioclastic selection is therefore very poor, including fragments of shells of less than $0.1 \mathrm{~cm}$, until complete nautilid shells of $30 \mathrm{~cm}$.

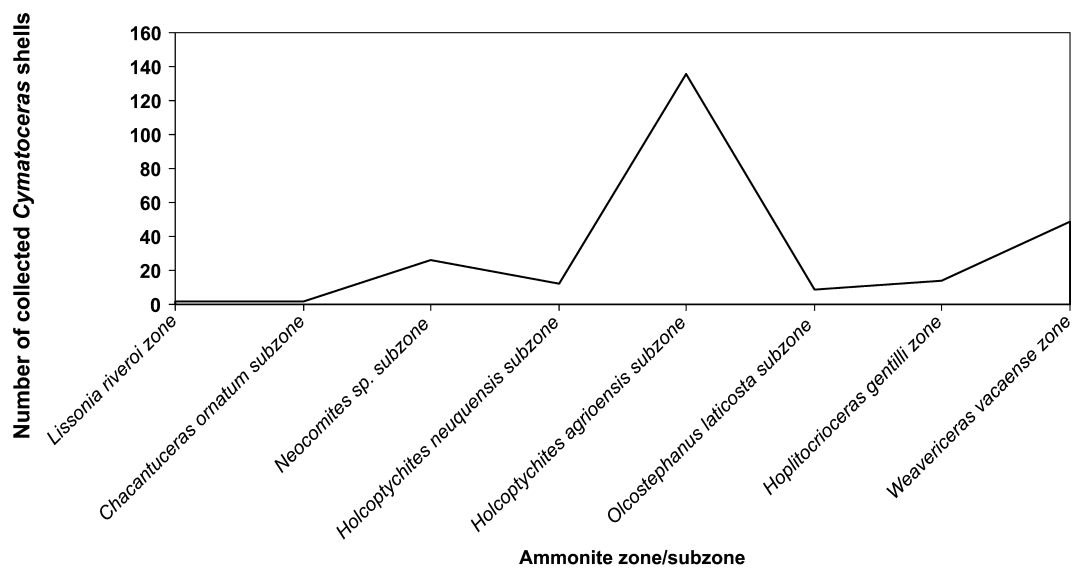

Fig. 3. Variability of the number of collected nautilid shells through the stratigraphic section including all localities shown in Figure 1, according to the ammonite biozonation of Aguirre-Urreta et al. 2007. 


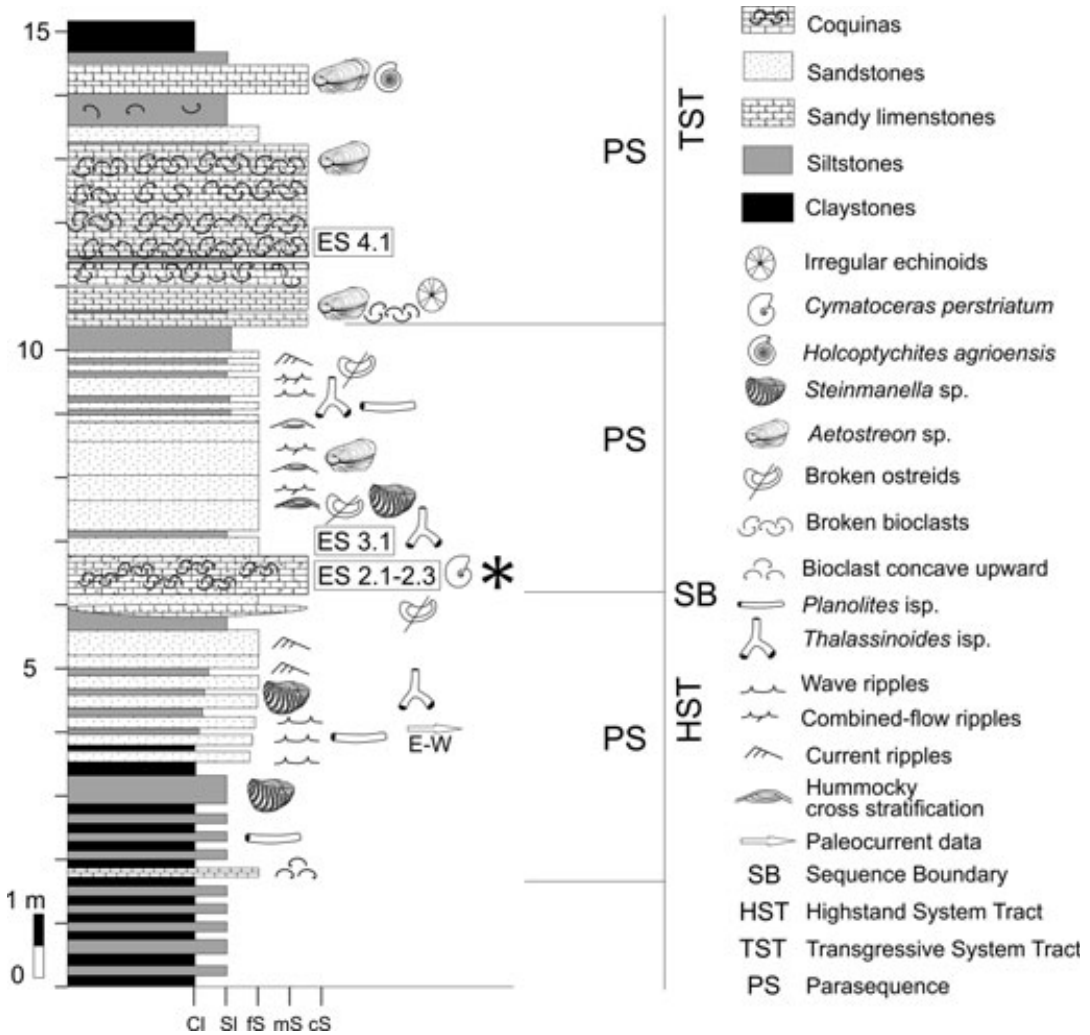

Fig. 4. Logged section within the Pilmatue Member, Agrio Formation, at El Salado Sur. The asterisk indicates the nautilid accumulation position. ES: petrographic samples.

Microscopically, the nautilid bed contains siliciclastic grains $58 \%$, allochems $35 \%$ and micrite $7 \%$ (ES 2.1-2.3, Figs 4, 5A-C) and is classified as an allochemic sandstone according to Mount (1984). The siliciclastic grains are largely composed by monocrystalline quartz and feldspar with some volcanic clasts and scarce biotite (Fig. 5A-C). The main types of allochems are undifferentiated bivalves and oyster fragments, and less undifferentiated bioclastic fragments (Fig. 5A-C). Echinoderms, foraminifers and serpulids were also recognized in low percentages. The nautilid shells are filled by non-ferroan sparry calcite (Fig. 5A) with dolomitized patches.

The amalgamated deposits are interpreted as the record of amalgamation of storms with increasing energy, taking into account the bigger sizes and abundance of bioclasts, and their mixing, from the base to the top of the interval. These types of deposits sometimes constituting archetypal clast-supported accumulations are very common in the Agrio Formation (Lazo 2007). Mount (1984) proposed a punctuated mixing to explain such fabric. Mixing occurs when sediment is transferred between contrasting depositional environments during rare, high intensity sedimentation events, like a storm. In that case, benthic communities are disrupted by a major storm but they can recover rapidly because relatively low input of siliciclastics takes place during fair-weather conditions. The shell infilling (Fig. 5A) indicates rapid burial and tight closure of the shells, which prevented sediment infiltration (Brett et al. 2006). The presence of articulated bivalves suggests also a rapid burial, along with the fact that not just the nautiloids but also the ammonites and bivalves are filled with calcite. That the bivalves are not in life position is not exclusive of a storm process, but accord with it and the lack of any pattern of deposition coincides with a rapid burial once more. The patches of shell fragments observed in the top of the bed could be generated through the formation of gutter casts during the storm (Aigner et al. 1978).

Other sandy limestones. - Other limestones were documented higher in the section than nautilid bed. Beds are 30-60 cm thick, occur isolated or amalgamated up to $140 \mathrm{~cm}$. Basal contacts are sharp or slightly deformed. The larger bioclasts, including ammonites, are mainly concentrated in the middle part of the bed. Silty limestones are intercalated, containing widespread non-orientated bioclasts and lacking internal stratification. Microscopically, one sample was studied (ES 4.1, Figs 4, 5D) and is a sandy allochemic limestone (sand $21 \%$, allochems $33 \%$ and micrite $47 \%$ ). 

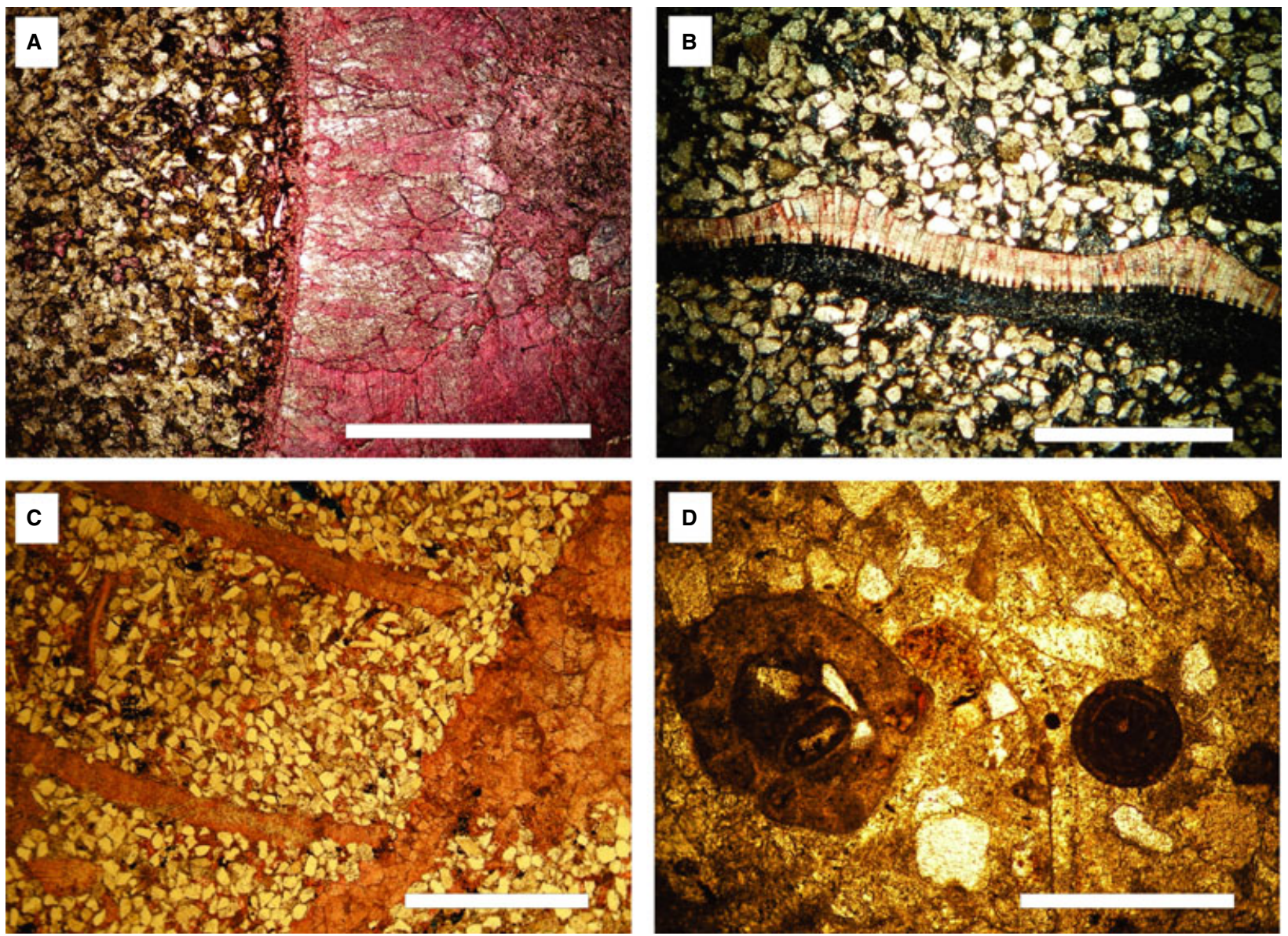

Fig. 5. Aspect of different petrographic samples. A, nautilid bed (sample ES 2.2): contrast between the siliciclastic and calcareous matrix and the sparry calcite nautilid shell stained pink (to the right). B, nautilid bed (sample ES 2-3): note the absence of bioerosion on the bivalve fragment in the abundant siliciclastic and calcareous matrix. C, nautilid bed (sample ES 2-3): abundant siliciclastic matrix (light) with minor amount of micrite and randomly oriented fragmented allochems (dark). D, other sandy limestones (sample 4.1): partially micritized tangential reworked ooid and intraclast with ooids in a calcareous with minor siliciclastic matrix. All samples colourless unless the D were stained with Alizarin Red and Potassium ferricianide. Pink stain reveals non-ferroan calcite, blue stain indicates ferroan calcite and siliciclastic materials remain unstained. Scale bar $=1 \mathrm{~mm}$ for all samples.

The main siliciclastic grains are monocrystalline quartz with subordinated feldspar, volcanic lithics and micas. The highly fragmented and undifferentiated bioclasts are the most abundant allochems. Notably, ooids stand out in the micritic matrix (Fig. 5D). They are reworked ooids accompanied by some intraclasts, and are the most important petrographic features with the nautilid bed. Most of the ooids have large nuclei and few laminae, and can be classified as superficial ooids (Strasser 1986). Minor proportions of tangential and micritized ooids were also identified (Fig. 5D). Generally, the ooids are partially or totally micritized and some of them are broken but not deformed. Comparatively in the nautilid bed, the last described sandy limestones exhibit a reduction in siliciclastic grains, similar proportions of allochems and a notable increase in micrite. The ooids are allochtonous and reworked particles (intraclasts) exported from shallow and agitated waters to be deposited as gravitational flows below the storm wave base level. Macroscopic features of the sampled bed support a gravitational flow interpretation based on the deformed and non-erosive basal contact that suggests rapid sedimentation, concentration of large-size bioclasts in the middle of the bed and absence of normal grading suggesting matrix strength as support mechanism. The abundance of fine-grained carbonate particles (allomicrite) is consistent with a matrix supported fabric and rheology of the flow. Microscopically, these deposits are similar to those described for the middle and outer ramp microfacies from Flügel (2004, p. 718).

\section{Siliciclastics}

Fine-grained deposits. - Fine-grained deposits are represented by intercalated claystone and siltstone beds, and each one is of decimetre-scale thickness. They are 

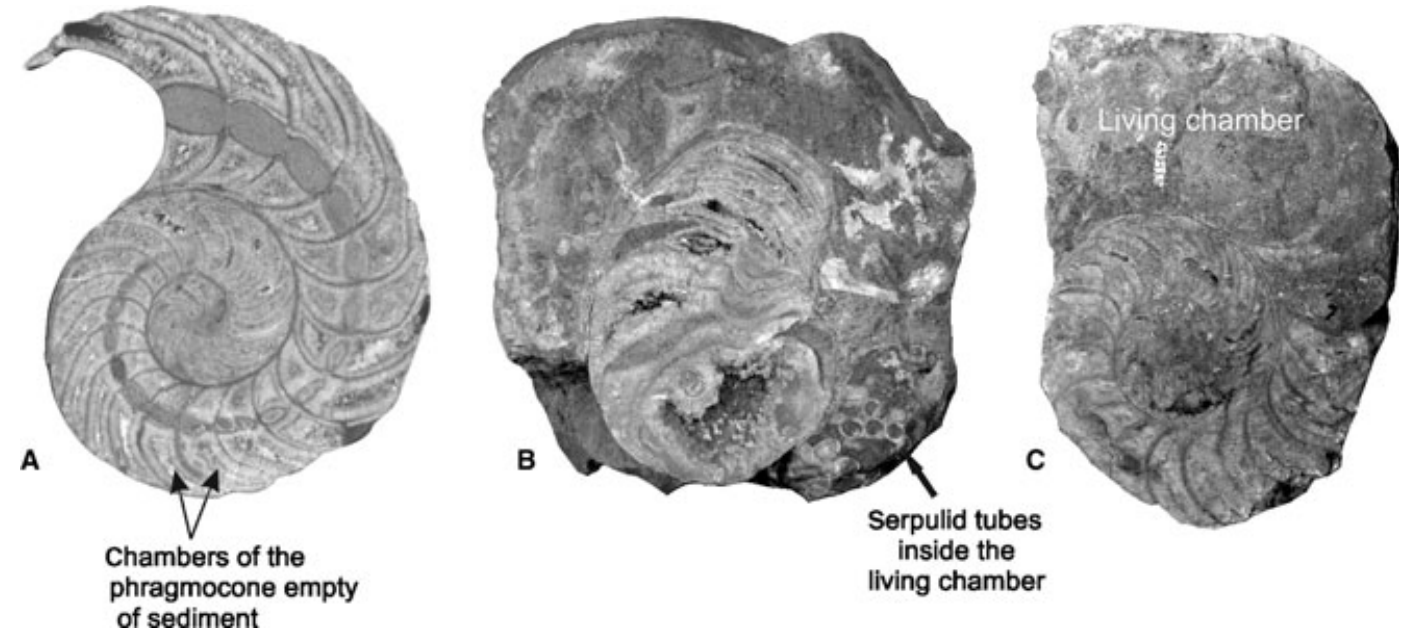

Fig. 6. Cymatoceras perstriatum (Steuer) collected from the bed with the accumulation of shells (Lower Cretaceous Pilmatue Member of the Agrio Formation, El Salado Norte). A, cut and polished specimen (CPBA 19850.1) showing the phragmocone chambers empty of sediment, but the siphuncle filled, magnification $0.5 \times$. B, naturally broken specimen (PI-6895.7-MOZ) showing grouped serpulid tubes inside the living chamber and some empty phragmocone chambers, magnification 0.5×. C, specimen CPBA 19843.38 naturally crosscut, showing phragmocone chambers empty of sediment and living chamber filled with it (the same as the sediment composing the nautilid accumulation bed), magnification $0.25 \times$

massive but, sometimes, faint parallel lamination occurs. In some intervals, the primary fabric is partially disrupted by bioturbation. Notably, shales are devoid of benthic body fossils, but bioturbated layers document the activity of deposit feeders, indicating intervals of low rate of sedimentation. These deposits are particularly well documented in the base and in the uppermost part of the logged section (Fig. 4). It has a fine upward trend, becoming shale-dominated and dark coloured, documenting the beginning of a thick fining-upward cycle due to a severe restriction in sand-size siliciclastic input. The scarcity of primary sedimentary structures could be not only due to the fact that these deposits constitute a monotonous deposition of fine-grained sediments settled from suspension, but also due to the result of clay flocculation, taking into account that variations of salinity have been proved recently by Lazo et al. (2008) for some intervals along the marine succession.

Heterolithic deposits. - Heterolithic deposits are composed of an interfingering of sandstones, siltstones and claystones, with an internal arrangement that usually starts with oscillatory ripples that pass upward to combined-flow ripples and finally to current-dominated types (Fig. 4). Palaeocurrent indicators measured from ripple crests show that wave ripples exhibit a dominant $\mathrm{E}-\mathrm{W}$ axis, while unidirectional crests and internal structures in current ripples show opposite trends with SE-NW axis. Some intervals are separated not only by veneers of claystones but also mud drapes, which were documented in some ripples.
This interval is interpreted as deposited in a progressive shallowing-upward setting that commences with fully oscillatory flows progressively replaced by combined and current flows. The palaeocurrents documented are congruent with a palaeocoastline mostly oriented NW-SE but opposite unidirectional ripples, mud drapes and clay veneers are indicative of tidal influence.

Sandstones. - Sandstone deposits are composed of decimetre scale beds, sometimes amalgamated up to $2 \mathrm{~m}$ thick. Internally, each bed contains asymmetrical hummocky-cross stratification that is usually covered by combined-flow and current ripples. Bioclasts are scarce and are recorded at the base of some beds. Basal contacts are irregular to clearly erosional. Petrographically, these rocks are fine to very fine sandstones composed by $50 \%$ of monocrystalline quartz, $35 \%$ of feldspar and 15\% of lithics (ES 3.1, Fig. 4), and can be classified as feldarenites (Folk et al. 1970). Scarce biotite flakes, opaques and zircon grains were also identified. Grains are angular and some lithics are altered to clay minerals conforming pseudomatrix and showing some deformation. The rim clay cement is the most common one. These deposits document storms in a mid-ramp depositional setting (Burchette \& Wright 1992). The bioclasts are lag-deposits accumulated during the waxing stage of the storm, while the combined-flow ripples indicate the winning stage. The occurrence of combined flow ripples and amalgamation suggests deposition over the fair weather wave base level. 

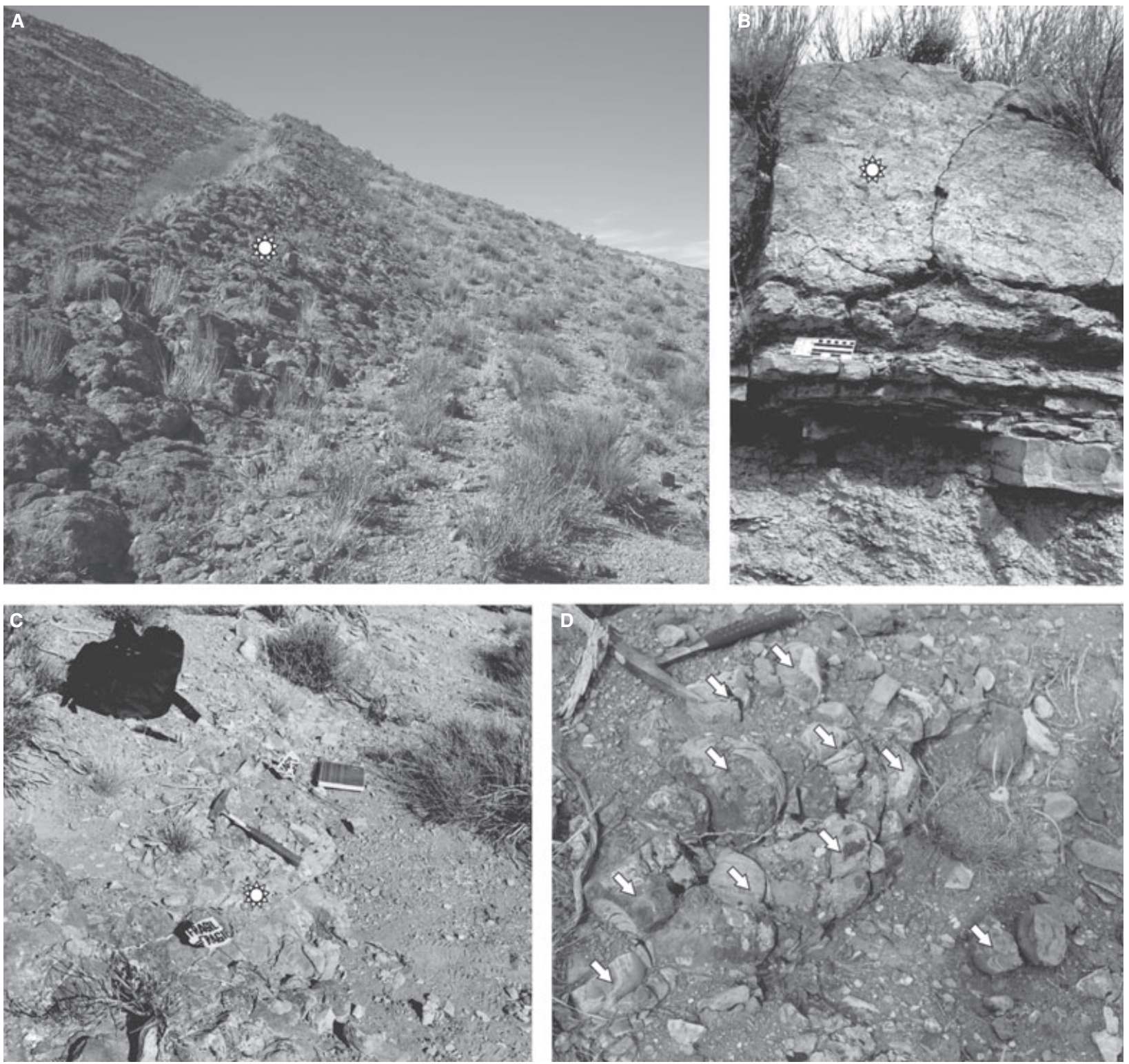

Fig. 7. Field photographs. A, B, El Salado Sur. C, D, El Salado Norte. The asterisk in A-C indicates the bed with the nautilid accumulation. Arrows in D indicate shells of Cymatoceras in a nested accumulation from which several remains were collected.

Sequence stratigraphy framework. - In the analysed section, two complete shallowing and coarsening upward packages interpreted as parasequences have been identified. The first one starts with a flooding episode documented by claystones, which are progressively replaced by heterolithic deposits in a notable coarsening and thickening upward trend (Fig. 4). The second one starts with the amalgamated sandy limestones containing nautilids. These beds suggest an increase of the accommodation space with clastic starvation, and up-section are replaced by siliciclastic wave dominated deposits over the storm wave's base level.

The boundary between these two parasequences is interpreted as a significant surface because there is a turnaround tendency in the stacking pattern from prograding to retrogradational, indicating a progressive increase of the accommodation space and probably is the conformable expression of a sequence boundary. Furthermore, the shallowest depth with tidal influence recorded towards the top of the lower parasequence is indicative of the maximum coastal progradation. A regional control on the proposed sequence boundary that confirms facies dislocation or a subaerial unconformity is necessary to reinforce our preliminary interpretation. In this scenario, the amalgamated sandy limestones containing the nautilid accumulation are interpreted as the beginning of a transgressive system tract. It is the moment when the siliciclastic input is progressively reduced, 

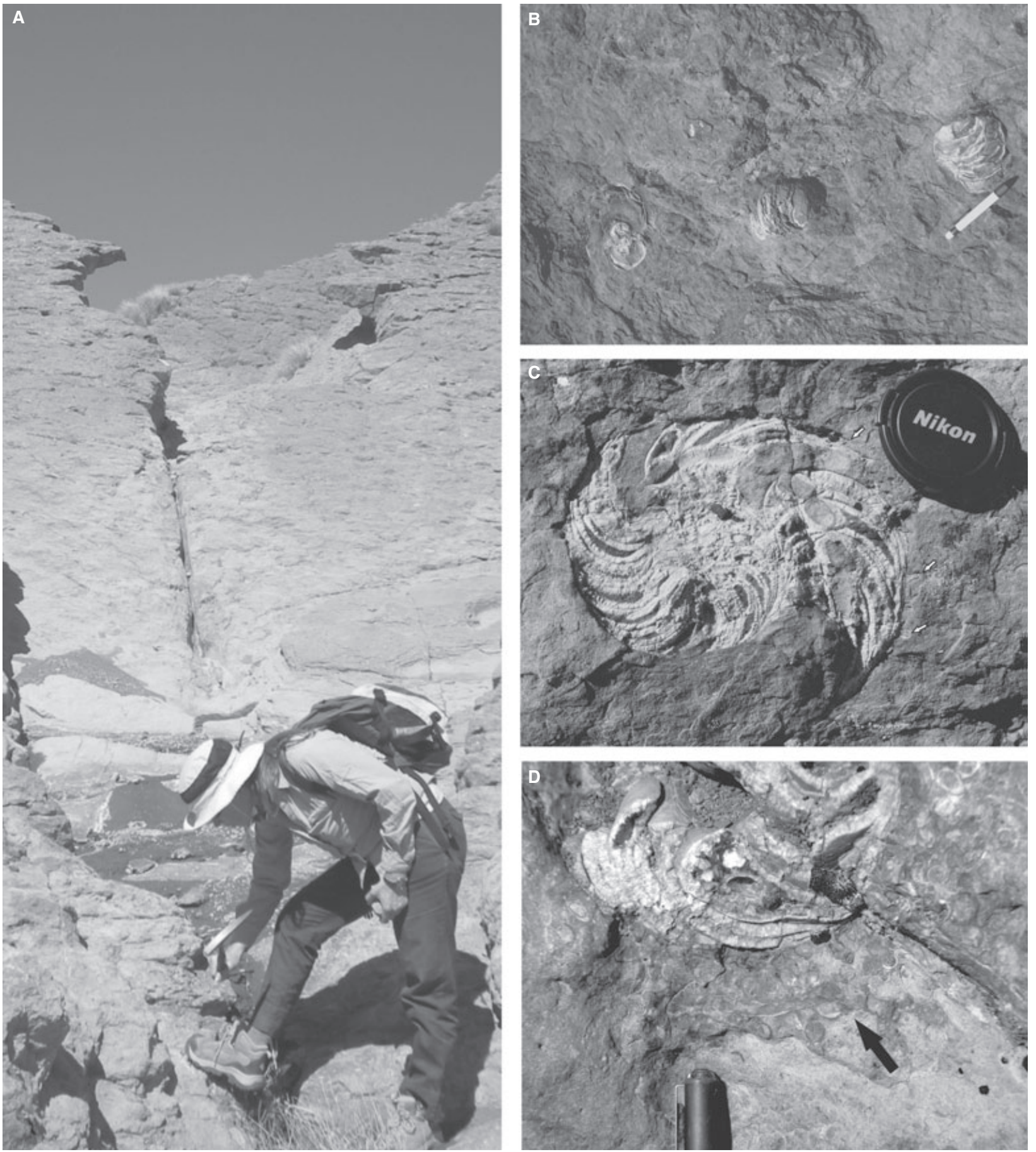

Fig. 8. Field photographs at El Salado Sur. A, view of the stratum with the nautilid concentration in the background. B, three shells in situ. C, D. Detail of two different shells. Arrows point to epizoans on the shell wall. Note the absence of sedimentary infill in phragmocone chambers.

accommodation space increases and remobilization of carbonate particles by storms is likely. Overlying the nautilid bed, the storms are documented by siliciclastic deposits containing hummocky-cross stratification (Fig. 4), evidencing that starvation in siliciclastic ends. The input of such particles documents the prograding and shallowing trend, typical in a wave-dominated parasequence. There is a third incomplete parasequence in the upper part of the section that is lacking in hummocky cross-stratification but exhibits a notable increase in micrite, severe reduction in siliciclastic particles and ooids and intraclasts exported from shallow waters of the inner to mid-ramp, confirming the advance of the transgressive system tract. Fluctuations in the sea level probably were the allocyclic control of the described interval. The combination 


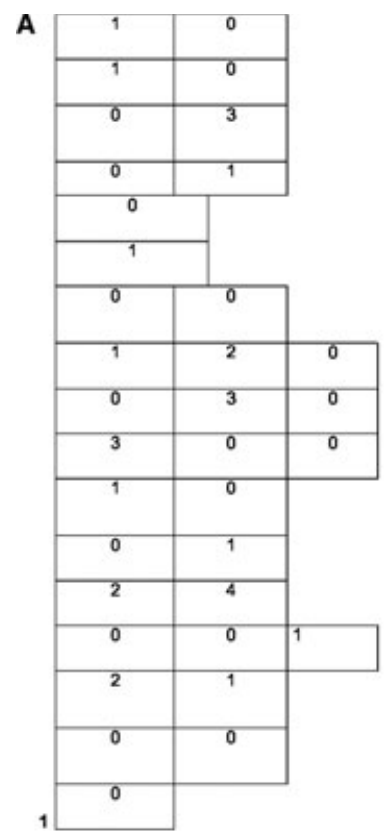

B

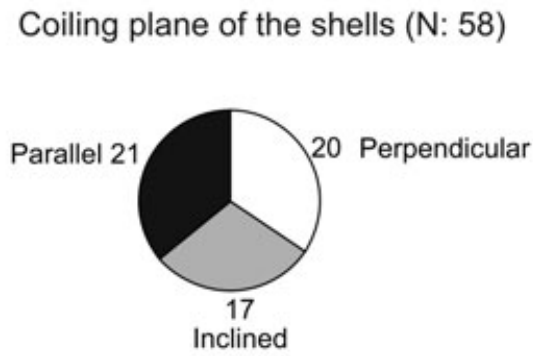

\begin{tabular}{|c|c|c|c|c|}
\hline 1 & 23 & 21 & 2 & 5 \\
\hline 0 & 0 & 0 & 0 & 6 \\
\hline 0 & 2 & 0 & 0 & 0 \\
\hline 2
\end{tabular}

\begin{tabular}{|l|l|}
\hline Number of stop & $\begin{array}{l}\text { Number of nautilid shells } \\
\text { in the stop }\end{array}$ \\
\hline 1 & 0 \\
\hline 2 & 2 \\
\hline 3 & 0 \\
\hline 4 & 0 \\
\hline 5 & 13 \\
\hline 6 & 0 \\
\hline 7 & 2 \\
\hline 8 & 0 \\
\hline 9 & 1 \\
\hline 10 & 0 \\
\hline
\end{tabular}

C

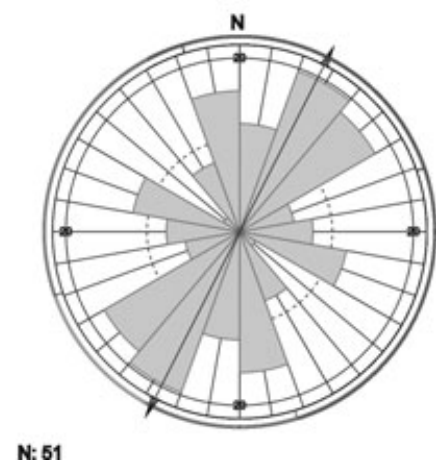

Fig. 9. Results of distribution and orientation analysis of the shells in the stratum. A, analysis of the spatial distribution of shells in the stratum. B, orientation of shells with respect to the bedding plane. C, trend of the major axis of the shells. (See text for explanation).

of shallow waters, storms and transgression is the combination that probably permitted this very peculiar accumulation of nautilids.

\section{Other post-Triassic nautilid shell accumulations}

Until now, the largest accumulations of nautilid shells were reported by Shimansky (1975) and Moore (1984). The first of these was in the context of a monograph on Cretaceous nautiloids of Russia, and mentions the existence of 250 shells of Cymatoceras (most of them of the species C. savelievi Shimansky) in sandy slope deposits, probable related to turbidity currents, but no taphonomic analysis was made (Shimansky 1975). In the second, Moore (1984) registered 180 specimens of Aturia angustata (Conrad) within spherical concretions in deep-water facies of the upper part of the Lincoln Creek Formation (Lower Miocene of southwestern Washington). This report was a whole study of the molluscan palaeontology and biostratigraphy of part of the Lincoln Creek Formation, and the author did not interpret the causes of the nautilid accumulation found. However, she mentions the presence of a nearly intact living chamber in most specimens. Zinsmeister (1987) described an unusual nautilid occurrence in the Upper Eocene La Meseta Formation (Seymour Island, Antarctica). It consists of 35 phragmocones mostly belonging to Aturia. All of them have some degree of abrasion, which suggests that they were deposited in a high-energy environment (e.g. beach) or during a reworking period along the shoreline earlier to the final burial (Zinsmeister 1987). Casadío \& Concheyro (1992) reported ca. 25 phragmocones of Hercoglossa romeroi (Ihering) in the 

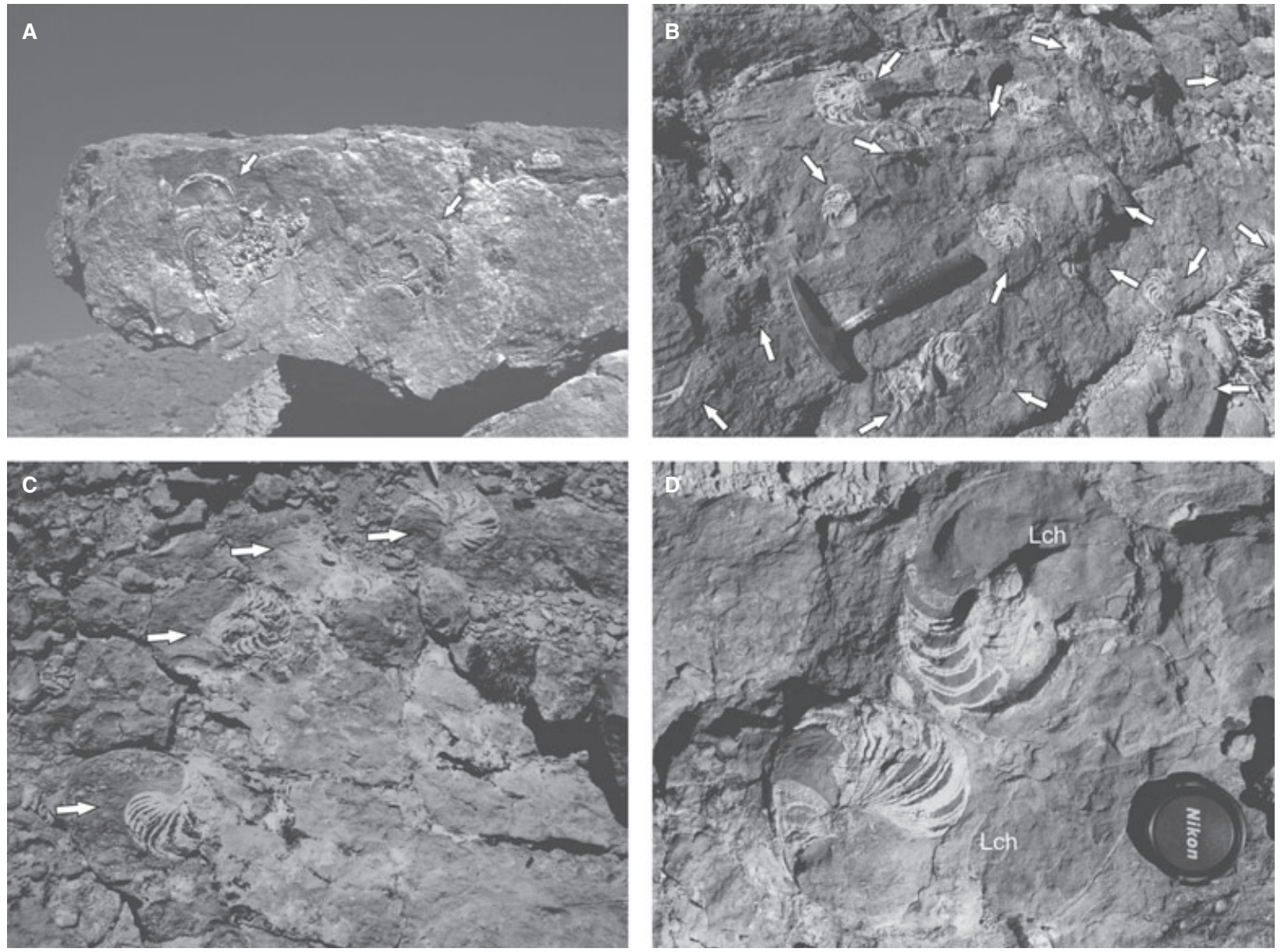

Fig. 10. Field photographs at El Salado Sur. A, view of two shells in a cut section. B, D, patches of shells in the stratum. Arrows indicate nautilid shells. Lch: living chamber.

Palaeogene Roca Formation (La Pampa, Argentina), interpreted as a shore drift deposit. Lukeneder et al. (1999) and Lukeneder \& Harzhauser (2002) also studied an Aturia concentration, from the Austrian Lower Miocene. This is an unusual co-occurrence of nautilids within a littoral to shallow sublittoral mollusc fauna, indicating a current-induced, and post-mortem drift of the Aturia shells (Lukeneder \& Harzhauser 2002). They reported ca. 30 cephalopod shells. The nekroplanktonic drift would be rather common for this genus due to their long septal necks (impermeable part of the siphuncle), that make it difficult for the entry of water to chambers, keeping thereby the positive buoyancy of the conch (Chirat 2000).

\section{Morphological and palaeoecological traits of Cymatoceras perstriatum}

The shell of $C$. perstriatum is large in adult stage, reaching $300 \mathrm{~mm}$ in diameter. It has a globular to sub globular shape, and its living chamber occupies half a whorl. The siphuncle passes between the central and dorsal part of the septa, and has a rather large crosssection. A detailed morphological description can be found in Cichowolski (2003). The SSI (Septal Strength Index) of Westermann (1973) was calculated for two specimens: CPBA 19854 and CPBA 19842 (Cichowolski 2004), to estimate the maximal habitat depth of the species. To do this, thin sections of the shells (in a longitudinal plane) were used, estimating the SSI of one septum from each specimen. The thickness of the septa was measured by use of the light microscope (considering always the thinnest part of the septum), and the radius of curvature was estimated by graphic methods. The thin sections were scanned and, over the scanned image, a circle was draw. The radius of that circle was considered as the radius of curvature of the septum.

These estimations are biased by the size of the thin sections $(5 \times 7 \mathrm{~cm})$ and the position of the septa that could be measured (because of the preservation), being impossible to calculate the SSI for the last septum. However, the ontogenetic variability in the 
implosion depth is considered irrelevant for Mesozoic and Tertiary nautilids (Hewitt 1989; Landman et al. 1994). The SSI obtained are 11.8 for the first specimen (at the $12^{\text {th }}$ septum), and 10.8 for the second one (at the $16^{\text {th }}$ septum), indicating an implosion depth of ca. $350 \mathrm{~m}$, based on the calibration curve of Westermann (1973). The safety factor between maximal habitat depth and implosion depth of Westermann (1999) was used, resulting in $350 \mathrm{~m} / 2: 175 \mathrm{~m}$. Regarding the locomotion abilities, despite the small umbilicus of this species, their globular conch and wide whorls would indicate an inefficient swimming capacity (Chamberlain 1976).

\section{Taphonomic features of the nautilid accumulation}

\section{Materials and methods}

The bed containing the nautilid shells is ca. $70 \mathrm{~cm}$ thick, with a strike of $0^{\circ}(\mathrm{N}-\mathrm{S})$ and a dip of $31^{\circ} \mathrm{W}$ (Fig. 7A, B). This stratum has a lateral continuity of at least $2 \mathrm{~km}$. It was registered in two areas of the $\mathrm{El}$ Salado locality: El Salado Norte and El Salado Sur. At the El Salado Norte locality it discontinuously crops out, being partially covered and highly weathered in some places (Fig. 7C, D). The nautilid remains were found both loose as in situ, but due to the intense alteration of the rock, the in situ specimens were easily removed. 'Nested' accumulations of ca. 10 shells were observed in situ (Fig. 7D), but also some isolated shells were found. Eighty specimens were collected from that single bed at this site, and were studied in the laboratory.

At the El Salado Sur locality (where the sedimentary log was done) the same bed crops out in a more continuous way, being much less weathered (Figs 7A, 8A). All the specimens were found in situ, and were very difficult to extract (Fig. 8B-D); as such the nautilids there were studied in the field.

Some taphonomic features of the shells were analysed to describe the concentration in detail. Those studied in situ were analysed for specimens of the El Salado Sur, whereas some characteristics of the shells (like incrustation, abrasion, etc.) were analysed in the collected specimens $(N=80)$, and, when possible, also in the in situ shells (e.g. the state of the living chamber, or the diameter, could be observed in the field for some embedded shells also).

Spatial distribution. - Two areas separated by a distance of ca. $300 \mathrm{~m}$ (one of ca. $60 \mathrm{~m}^{2}$ and other of ca. $120 \mathrm{~m}^{2}$ ) were chosen to analyse the nautilid distribution in the stratum. To visualize the spatial distribution, in each area the top of the bed was divided into squares of $2 \mathrm{~m}^{2}$ and the number of nautilid shells within each of them was counted (Fig. 9A1, 2). Shells observed in the section of the stratum were also considered when they corresponded (Fig. 10A). We planned to include a larger area of counting, but due to the difficulty of evaluating the whole outcrop of the stratum, the analysis was extended through an area of $320 \mathrm{~m}^{2}$ in the following way: walking along the border of the inclined bed, stopping each $5 \mathrm{~m}$, and delineating in each stop an area of $2 \mathrm{~m}$ along the border (in the horizontal plane) and covering the whole height of the stratum (ranging between 2 and $4 \mathrm{~m}$, depending on the outcrop in each stop). In every area the nautilid shells were counted (Fig. 9A3).

Orientation of the shells with respect to the bedding plane. - The burial orientation of the shells (the inclination of the coiling plane related with the bedding plane) in the specimens found in situ was analysed. The coiling plane is that which contains the siphuncle and is perpendicular to the coiling axis. This parameter was divided in three categories: coiling plane parallel, perpendicular, or inclined respecting to the bedding plane, and could be evaluated in 58 samples (Fig. 9B).

Orientation: trend of the major axis of the shells. - To study possible tendencies in the orientation respecting the bearing of the shells, the trend of the major axis was measured with the compass in all possible cases (51 specimens). The major axis of a shell is the direction of the line that goes from the peristome (or from the external border of the shell when the living chamber is broken or absent) until the most adapical part of the conch, through the median longitudinal plane (Fig. 9C). It should be noted that bidirectional data were used, and therefore in the graphic only $180^{\circ}$ must be considered.

Taphonomic traits of the shells. - Both in the collected shells at the laboratory, as well as in some of the shells observed in situ, the following traits were analysed.

Living chamber. - The condition of the living chamber was classified with three states: complete/almost complete, broken (partially present) or absent. This parameter was mainly analysed for in situ specimens at El Salado Sur, because of the previously mentioned high alteration of the shells collected at El Salado Norte, which most times were fragmented when found loose or when removed from the stratum. 
Breakage pattern. - The breakage pattern of the shells was evaluated and characterized, describing the commonest affected zones of damaged. It is important to elucidate between breakages during the pre-burial phase from those due to lithostatic charge.

Shell size. - The size of the specimens was measured as the maximum preserved diameter in shells with at least part of the living chamber preserved (Fig. 11). As no size selection was presumed in the bioclasts of the bed bearing nautilid shells, the size of the specimens that preserve at least part of the living chamber was considered to evaluate potential palaeoecological implications. The possible existence of sexual dimorphism was not considered here because it was not suspected during previous studies on this species along different beds and localities of the Neuquén Basin (Cichowolski 2003). Collected specimens with living chamber are not so numerous $(N=45)$ because of the high disarticulation observed at El Salado Norte, but this trait could also be evaluated in some cases in the in situ shells at El Salado Sur.

Abrasion and dissolution. - These processes were evaluated and described. The abrasion was mainly analysed taking into account the presence of facets as described by Müller (1979). The dissolution was estimated evaluating the state of the shell as high, medium or low.

Encrustation and bioerosion. - The region affected on the nautilid shells, and the type of encrusting and bioerosion were analysed, considering the probable period when they occurred (during life or after death of the animals). However, it is worth noting that in collected specimens of the El Salado Norte, the high degree of fragmentation of shells made it difficult to estimate this parameter in a systematic way. The observation of the shells in the stratum (at the El Salado Sur) not always provided their whole view to estimate the importance of this parameter. In any case, a general appreciation was accomplished with the material available.

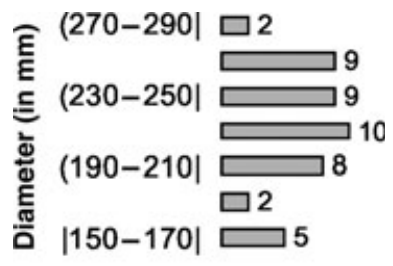

Frequency

Fig. 11. Frequency of different nautilid shell diameters with at least part of the living chamber collected at El Salado Norte.
Sedimentary filling. - The patterns of sedimentary filling of the shells were analysed to reconstruct their taphonomic histories. This could be done by direct observation of sectioned specimens, both naturally cut and those that were cut and polished at the laboratory (Fig. 6A-C)

\section{Results}

The grills made to evaluate the spatial distribution show that the shells are disposed in patches within the stratum (Figs 9A, 10B-D). Furthermore, Figure 9B shows that there is no particular tendency in the orientation of the shells regarding the coiling axis; instead, the proportions are equivalent for the three categories described above, suggesting a random disposition. However, it can be seen in Figure 9C that there is a predominant disposition of the major axis of the shells in a NE-SW direction.

Regarding the preservation of the shells, most specimens show the presence of an almost complete living chamber (Type-A of Maeda et al. 2003), as seen in Figure 10B-D. However, in some cases, depending on the position of the shell within the stratum, it could not be seen even if it is present. Sometimes it appears that the lack of that part of the shell was due to recent weathering and erosion and not because of breakage during the biostratinomic drift. In addition, most nautilid shells are nearly intact in shape, while just a few of them show different levels of shell damage.

The results of the size frequency analyses show that the most common interval is between 19 and $27 \mathrm{~cm}$ of shell diameter, the smallest interval being of not less than $15 \mathrm{~cm}$ (Fig. 11). The degree of abrasion in the shells of this bed is generally high, the contours being commonly rounded. Some possible truncation facets (Müller 1979) were observed of the kind that Fernández-López (1984) called truncation by denudation, with reference to the abrasion of external surfaces during the partial unearthing of the shells or internal moulds. In this way, the elements can be truncated more or less parallel to the stratification of the included materials. In the case of the nautilids, some shells were truncated irregularly through the sagital plane, with abrasion of the exposed surface (Fig. 6C).

The shell wall of most specimens of $C$. perstriatum is almost completely dissolved (Fig. 6A, C). Exceptions are seen in some parts of the shells that are encrusted by epizoans. The septa are usually preserved, with the exception of those adjacent to chambers filled with sediments (which are extremely rare in shells of this stratum), that are usually dissolved. Septa are in contact with each other through their ventral 
parts, permitting the preservation of the shells as hard parts (although recrystallized), and not as internal moulds, in the great majority of the cases. In this way, chambers are usually empty of sediment, but cemented (Figs 5A, 6A-C).

Some variability in the pattern of bioerosion and encrustation was detected. Several specimens are free from epizoans, or there is some isolated oyster or serpulid encrusting the umbilical or periumbilical area. In some cases a low density of epibionts are encrusting the shell (generally on the last whorl of the phragmocone or laterally on the living chamber). However, in a few cases, the encrustation is much higher, with several serpulids and oysters cemented to the last whorl of the nautilid shells (Fig. 8C, D). There were also found around six specimens that have numerous serpulid tubes adhered to the inside of the living chamber (Fig. 6B), being filled with the same sediment as the living chamber of the nautilids (that is the same sediment that composes the matrix of the bed). If epizoans are on the external shell wall, they are incrusting surfaces of the shell where the dissolution is not too high. Epizoans over dissolved areas (internal moulds) of the shells are rare.

Most specimens of this stratum are not bioeroded but a few shells have traces of the activity of other organisms, mainly clionid sponges and undetermined vermiform animals. Sometimes these traces are on the internal mould of phragmocone chambers, whiles in others, the traces are on the shell. It can be seen that sometimes the traces allowed the sediment to enter into the chambers that anyway are found empty.

The pattern of sedimentary filling of the collected and in situ specimens (as could be seen in the outcrops) is relatively homogeneous. In general, the phragmocones are mainly empty, with just a few chambers filled with sediment (Fig. 6A-C). These are usually those adjacent to the living chamber, or those with the wall perforated by bioerosion, as mentioned above. The living chamber (or the last phragmocone chamber preserved when it is absent), is filled with the same sediment than that of the matrix of the bed under study (Fig. 6C). The siphuncle is filled with sediment until different levels in different shells, sometimes until the chambers of the first whorl (Fig. 6A).

\section{Discussion}

The shells accumulated in this stratum were probably shells that floated post-mortally, instead of being sunk and buried in the place where death occurred, considering both their morphological characteristics and the probable depth where C. perstriatum lived (Chamberlain et al. 1981; Cichowolski \& Aguirre-Urreta 2005).
The positive buoyancy of the cephalopod shells after death would be more common than previously thought, the possibility being high of post-mortem drift (Wani et al. 2005; Reyment 2008). This would be especially true for bigger shells than for smaller ones (Wani et al. 2005), and for shallow water inhabitants than for deep water ones (Chamberlain et al. 1981). Some taphonomic traits of the shells of $C$. perstriatum, along with the information provided by the petrographic studies, indicate that the bed where the accumulation is present corresponds to a storm event. The absence of sedimentary infill in the great majority of the phragmocone chambers suggests a rather rapid burial, also consistent with a storm event deposition. Nevertheless, the presence in some nautilid shells of a high number of epizoans suggests that at least part of the shells preserved passed some time floating in the water column before being buried.

The known accumulations of Recent Nautilus shells along the beaches near by the habitat of these animals are characterized by a high degree of damage, loss of the living chamber and part of the phragmocones, mainly due to violent wave action, especially impact on hard substrates as coral reefs, and biological destruction or alteration (Maeda et al. 2003 and references therein). According to Wani's (2004) experiments with Nautilus, floating shells are only fragmented during storm events, probably during high-energy collision against hard obstacles in a rocky shore. Wani (2004) observed that shells are never broken during flotation, except when they collided with hard flotsams. The main differences between Lower Cretaceous Cymatoceras accumulation and that of Recent Nautilus is the almost completeness of the majority of the Cretaceous shells, with a common presence of the living chamber, and a low degree of serious damage. When it is present, it is observed in the ventral part of the living chamber, which Wani's (2004) experiments have shown that is the most susceptible part of the shell to be broken during postmortem transport of cephalopod shells, excepting the aperture, where the shell is stronger. In contrast with what occurred with some of the previously mentioned accumulations of post-Triassic Nautilida (e.g. Zinsmeister 1987; Casadío \& Concheyro 1992; Lukeneder \& Harzhauser 2002), and also of Recent Nautilus, that of Cymatoceras is not a concentration of beached shells; they were buried in a mid-ramp environment and were not exposed subaerially (see above Sedimentology and sequence stratigraphy). It is probable that the differences between the palaeoenvironment represented by the Pilmatue Member of the Agrio Formation and the present day coastal environment where Nautilus species live (coral reef environment) or the high-energy beach environments in the cases of 
Cenozoic nautilids, had influence in the way that the shells are preserved in both cases. The absence of a rocky shore or an important reef development in the ancient marine ramp of the Neuquén basin would allow that shells of Cymatoceras drift during some time without suffering major destruction, until a sudden deposition during a storm event. The knowledge about traits of Nautilus shells accumulated in deeper waters is poor. Roux (1990 in Maeda et al. 2003) photographed one concentration of after death sunken shells, and a preliminary view suggests that it contains both shells damaged and undamaged. However, the eight Nautilus shells reported by Mapes et al. (2010b) from deep waters in New Caledonia, showed massive damage. Nevertheless, these deeper deposited shells are not concentrated due to a storm event, and then the comparison is not wholly proper.

Besides the differences in the depth at which the shells were deposited, shells accumulation at El Salado resembles beached Recent Nautilus shell accumulations in the patchy distribution (Matsushima 1990 in Maeda et al. 2003) and in the probable relationship with storm events. It is possible that Cymatoceras shells were deposited along a large area within a midramp environment during a storm event and, due to the turbulent currents related to the storm and the presence of irregularities in the sea bottom, where the shells would have been kept trapped, formed the patches now observed in the outcrops (Fig. 9A). The random disposition with respect to the bedding plane could be related with the nearly spherical shape of $C$. perstriatum conchs, which does not favour any particular orientation, and facilitated by a rapid burial (Fig. 9B). It could be that the major axis of the shells has been slightly reoriented in the above mentioned direction by reworking through oscillatory currents before the final burial (Fig. 9C). However, if the burial was a sudden event, it is improbable that an important reorientation of shells by posterior currents occurred.

The dominance of adult specimens in the accumulation coincides with the most common record, not just for C. perstriatum, but also for other species of post-Triassic Nautilida. Furthermore, Recent populations of Nautilus have dominance of adults too, apparently due to habitat segregation for reproduction and related to the k-strategy of reproduction known for these animals (Saunders \& Ward 1987). According to Reyment (2008), the results reported by Wani (2004, 2007), in which he observed that juvenile shells become more readily waterlogged than adults, and hence juveniles could be buried in sediments near to where they lived in contrast to adult shells, which could also explain the usual absence of juvenile shells in the fossil record. However, Reyment (2008) points to the assumption in this theory about a very high juvenile mortality of ancient and modern shelled cephalopods, considering it unreal.

The high degree of abrasion and the truncation facets observed, suggest a high-energy environment of deposition, although this kind of alteration could occur later, during an exhumation period after cementation of shells. The high degree of dissolution of the shell wall is probably related with the water chemistry and the high porosity of the bed where the shells are preserved (Fernández-López 2000). The presence of the septa is possible due to their internal position, being not directly in contact with the solutions of the medium that are sub saturated in carbonates. Regarding the presence of epizoans on parts of the shells that are not dissolved, may be related to the fact that oysters and serpulids are calcitic in composition, and then they resist longer than the cephalopod aragonite to the dissolution processes. Therefore, the incrustation zones of the shells are 'protected' from dissolution by the presence of epizoans.

Considering the pattern of sedimentary infill of the Cymatoceras shells at El Salado, it is proposed that the burial was rapid. However, the presence of some specimens with a high density of encrustation indicates that they were exposed to the action of epibiosis during some time prior to final burial (at least some weeks, see Donovan 1989), to allow oysters and serpulids to develop and growth (Figs 6B, 8C, D). Low density patterns of encrustation could occur during life of the animals, as is seen on Nautilus (Saunders \& Landman 1987). However, and although the colonization of the interior of the living chamber during the life of the cephalopod was observed in Nautilus at present (Landman et al. 1987), considering the number and size of the serpulid tubes within $C$. perstriatum (Figs 6B, 8D), in this case it seems most probable that the colonization had occurred after death. Comparable cases on ammonites were reported by Lukeneder \& Harzhauser (2003), describing serpulids using the empty shells as cryptic habitats. Also the presence of several oysters on the external ventral part of the living chamber is difficult to assume if the buoyancy and locomotion necessities of the living organisms are considered (Mapes et al. 2010b). Based on the pattern of sedimentary infill is that we suggest that the process of epibiosis occurred during the post-mortem drift of the shells in the water column. By contrast, encrustation inside the shells could also occur during a brief stay at the bottom, while sedimentary infill of living chambers was partial (Lukeneder \& Harzhauser 2003). However, if the shells would have passed long time at the bottom they should show a more complex pattern of sedimentary infill (Fernández-López 1997) as seen in others C. perstriatum shells found at the Agrio Formation, in different beds and localities, mainly in 
rather thin beds interpreted as distal tempestites (Lazo 2007). Cases of epizoans colonizing floating shells were reported previously and are considered a rather common success (Donovan 1989 and references therein; Lukeneder 2005). Regarding the time necessary for epizoans to develop, Donovan (1989) mentions an example of a modern species of oyster that shows growth of $1 \mathrm{~mm}$ per day. Therefore, highly encrusted shells of Cymatoceras could have been floating during one month or a little more time before being trapped by reflux currents of a severe storm. After the burial of shells during the storm, it is also probable that some of them were partially unearthed, after cementation occurred and once internal moulds of the living chambers were formed, and then they might have been subjects of additional alteration as abrasion, bioerosion and encrustation again.

It is interesting to note that the bed containing this nautilid accumulation is not the only tempestite of the Agrio Formation. Furthermore, there are many others considered as tempestites (Spalletti 1992; Lazo 2007), but this bed at the El Salado locality is unique in containing a nautilid accumulation with the characteristics described herein. The possible causes are worthy to be discussed. As previously mentioned, within the shells accumulated in this bed there is a probable mix of recently 'produced' empty shells, and others who might have floated for some time. However, the high availability of shells is remarkable.

As mentioned above, the bed in question is at the base of a parasequence, where the sedimentation rate is associated with storm events, while during fairweather intervals the clastic influx is very low. Furthermore, this bed is within the most shallow part of the section, and then the conditions to accumulate floating objects are higher than in deeper parts. This basin context could favour the accumulation of shells. What is curious is that other ectocochleate cephalopod shells as ammonites are not concentrated in the same bed. Although some shells of Holchoptychites agrioensis were observed along Cymatoceras in the same stratum, and even preserved in the same way (without sedimentary infill in the phragmocones) they are in the usual abundance. This observation could be related with the different biostratinomic pathways usually followed by nautilids in contrast with ammonites, in particular those with compressed shells as Holchoptychites (Cichowolski 2004; Cichowolski \& Aguirre-Urreta 2005).

It is probable that accumulations of nautilid shells on beaches were a rather common phenomenon, but as expectable, their fossilization potential would be very low. Nevertheless, these floating shells could be trapped by a storm process and be carried to a deeper environment with high volumes of sediment transported from the shore, before being rapidly buried.

A palaeobiological consideration related with the causes of this high number of shells available to be buried cannot be rule out. Behavioural patterns are much more studied for coleoids than for nautiloids (e.g. Boal 2006; Barbato et al. 2007; Graso \& Basil 2009), and gregarious behaviours are known for example in squids, for which schooling behaviour was reported, and probably in belemnites (Rawson 2000; Boletzky 2001). For nautilids, nothing similar was reported. Mass stranding of squids have been registered due to low salinities events in the North Sea (Reyment 2008). Equivalent processes were suggested to occur in fossil coleoids and orthoconic Palaeozoic nautiloids, not only related with salinity changes but with other biological or geological factors that can generate a mass mortality of cephalopods (Holland et al. 1994). These findings were interpreted as evidences of schooling behaviour. In belemnites, huge amounts of shells (belemnite battlefields of Doyle \& MacDonald 1993) were considered as catastrophic mass mortality, post-spawning mortality and other causes. Holland (1979) related the concentrations of shells of modern Nautilus found in the south-west Pacific to mass-mortality after mating, but this interpretation does not seem to be correct, based on the knowledge of its biology. Ecological characteristics of Nautilus and post-Triassic Nautilida seem to be very different from belemnites and other coleoids, most Palaeozoic nautiloids, and even ammonoids, whose mode of reproduction is more similar to coleoids than to nautilids, as evidenced by reports of huge number of ammonitellas and by their morphological characteristics (e.g. Kulicki 1979; Kulicki \& Doguzhaeva 1994). The k-strategy of reproduction in Nautilina (versus the r-strategy inferred for ammonoids and known for most coleoids) is perhaps the main difference that cause influences in the population dynamics.

In the case of the accumulation of shells of Cymatoceras at El Salado, it is difficult to estimate if there was a mass mortality event. The apparent mix of shells that were floating some time (although they would be a minority) and others that were probably buried nearby after the death of the animals, suggests that if it was a mass mortality, it affected most preserved nautilids but probably not all of them. Lazo et al. (2008) studied salinity changes along the Agrio Formation and the data of the $H$. agrioensis subzone coincides with a normal value; then, this kind of environmental change should be discarded as the cause of mortality. One can imagine also that in such a case when salinity considerably drops, other marine groups should be importantly affected, being the most obvious that of 
ammonites. However, ammonites, as previously mentioned, are not found in extreme abundance at this bed. Although may be not in the same bed, a higher number of ammonites should be present within a closed interval if a low salinity was the cause of a mass mortality.

Some observations of Recent Nautilus related with changes in abundance of individuals are that of Talavara \& Faustino (1931 in Reyment 2005), who reported that in several areas around the Philipines $N$. pompilius appears periodically with a maximum during the summer months. Seasonality in abundance of specimens was also noted in Spirula spirula (Lukeneder et al. 2008). However, Reyment (2005) pointed that in Nautilus this periodicity could be possibly due to local vertical migration and not due to an active geographical displacement, as the energy required for seasonal migration over vast distances cannot conceivably be mustered by shell-bearing cephalopods. However, Chirat \& Rioult (1998) have reported special sites for oviposition in Jurassic Nautilida, comparing them with recent sites in Nautilus and relating it with the dominant presence of adult shells in the fossil collections of post-Triassic Nautilida. Considering that the sites where nautilids laid eggs would be very specific (with several environmental requirements) and laterally limited in outcrops, and taking into account the palaeoecological characteristics of most Mesozoic and Cenozoic nautilids, Chirat \& Rioult (1998) suggested that these animals should migrate laterally to lay their eggs. This would contrast with the vertical migrations of present day Nautilus, who lay their eggs at shallower waters than the waters where they live. These palaeoecological features could imply some lateral migration, and may be associated with some gregarious behaviour, but nothing that can be demonstrated with the accumulation herein reported.

A mass stranding of argonauts (Cephalopoda, Argonautidae) was reported by Demicheli et al. (2006) along the Uruguayan southwestern Atlantic coast, and related it with singular oceanographic and meteorological conditions that advected oceanic warm waters towards the shore. Similar mass stranding of Argonauta shells was personally observed by one of us (María Beatriz Aguirre-Urreta) in South Africa (Cape Town). As result of storms with west and northwestern winds, argonauts accumulated at the shore, while with storms with different wind directions the stranding did not occur. May be the end cause of these strandings would be related with that suggested by Demicheli et al. (2006) at Uruguay. We could consider an equivalent scenario for Cymatoceras in the Neuquén Basin, but an important difference is that in the argonauts the females segregate the shell before they laid their eggs, as an incubatory chamber, and that they are gregarious for reproduction. Furthermore, the buoyancy characteristics of both animals are dissimilar. If the cause of the accumulation was just the storm winds' direction, probably there should be another kind of shells' accumulation, but it is not the case. Again, we can argue that nautilid shells were floating while probably most ammonite shells were not.

It is impossible to define a unique cause for the presence of such accumulation of nautilid shells. Furthermore, we believe that more than one factor should have existed leading to its formation. A high number of shells needed to be present at the moment the storm occurred and buried them. The storm could be related with the death of some of the nautilids whose remains are now accumulated (and then probably some gregarious behaviour had occurred), or may be the death occurred before the storm in most cases. If the latter case were considered, the high number of shells would be probably related with the basin context at that moment (during a transgressive stand system tract). Surely, some shells were also floating at the time the storm occurred, at least those that are heavily encrusted. The rapid burial of the shells, any one being the origin, was directly related with the storm processes. The almost completeness of most shells, with common presence of the living chamber, would be related with the kind of palaeoenvironment where $C$. perstriatum lived, without reef barriers or rocky shores to collide and be broken. This accumulation is the biggest of all previously known ones in a shallow-water environment for post-Triassic Nautilida.

Acknowledgements. - The authors are especially grateful to Peter Rawson (UK) who found the nautilid accumulation, and for his help in the field work. We also thank the help in the field of Sue, Anne and Jane Rawson, Romina Sanci, Darío Lazo, Andrea Concheyro and Guillermo Ottone (University of Buenos Aires, Argentina). We want to offer special thanks to Family Quilapi (El Salado) for their kindness and hospitality. We are especially grateful to the important help of Roberto Raggi (Buenos Aires, Argentina) for translations of literature in Russian. The revisions by Haruyoshi Maeda (Kyoto University) and Alexander Lukeneder (Natural History Museum of Vienna) greatly improved the original manuscript. We thank Peter Doyle for the editorial work. This work was financed by grants PICT 189 and UBACyT X001 (to M.B. Aguirre-Urreta), and the Paleontological Research Institution Award (to M. Cichowolski). This is the contribution R-14 of the Instituto de Estudios Andinos Don Pablo Groeber.

\section{References}

Aguirre-Urreta, M.B., Mourgues, F.A., Rawson, P.F., Bulot, L.G. \& Jaillard, E. 2007: The Lower Cretaceous Chañarcillo and Neuquén Andean basins: ammonoid biostratigraphy and correlations. Geological Journal 42, 143-173.

Aigner, T., Hagdorn, H. \& Mundlos, R. 1978: Biohermal, biostromal and storm generated coquinas in the Upper Muschelkalk. Neues Jahrbuch für Geologie und Paläontologie Abhanlungen 157, 42-52. 
Barbato, M., Bernard, M., Borelli, L. \& Fiorito, G. 2007: Body patterns in cephalopods. 'Polyphenism' as a way of information exchange. Pattern Recognition Letters 28, 1854-1864.

Boal, J.G. 2006: Social recognition: a top down view of cephalopod behaviour. Vie et Milieu - Life and Environment 56, 69-79.

Boletzky, S.V. 2001: The visual world of hatchling and juvenile cephalopods. Advances in Ethology 36, 86.

Brett, C.E., Allison, P.A., Tsujita, C.J., Soldani, D. \& Moffat, H. 2006: Sedimentology, taphonomy and paleoecology of meterscale cycles from the upper Ordovician of Ontario. Palaios 21, 530-547.

Burchette, T.P. \& Wright, V.P. 1992: Carbonate ramp depositional systems. Sedimentary Geology 79, 3-57.

Casadío, S. \& Concheyro, A. 1992: Facies y ambientes de sedimentación en el límite Cretácico-Terciario de La Pampa, Argentina. Actas VIII Congreso Latinoamericano de Geología (Salamanca) 4, 30-34.

Chamberlain, J.A. 1976: Flow patterns and drag coefficients of cephalopod shells. Palaeontology 19, 539-563.

Chamberlain, J.A.. Jr, Ward, P. \& Weaver, J.S. 1981: Post-mortem ascent of Nautilus shells: implications for cephalopod paleobiogeography. Paleobiology 7, 494-509.

Chirat, R. 2000: The so-called 'cosmopolitan palaeobiogeographic distribution' of Tertiary Nautilida of the genus Aturia Bronn 1838: the result of post-mortem transport by oceanic palaeocurrents. Palaeogeography, Palaeoclimatology, Palaeoecology 157, 5977.

Chirat, R. \& Rioult, M. 1998: Occurrence of early post-hatching Jurassic Nautilida in Normandy, France: palaeobiologic, palaeoecologic and palaeobiogeographic implications. Lethaia 31, 137-148.

Cichowolski, M. 2003: The nautiloid genus Cymatoceras from the Cretaceous of the Neuquén and Austral basins, Argentina. Cretaceous Research 24, 375-390.

Cichowolski, M. 2004: Nautílidos del Cretácico de Argentina (Cuencas Neuquina y Austral) y Antártida (Cuenca James Ross), 307 pp. Unpublished $\mathrm{PhD}$ thesis, Universidad de Buenos Aires, Argentina.

Cichowolski, M. \& Aguirre-Urreta, M.B. 2005: Comparación entre las rutas tafonómicas de los amonites y los nautílidos de la Formación Agrio (Cretácico). Actas XVI Congreso Geológico Argentino, 333-336. La Plata, Buenos Aires.

Demicheli, M., Martínez, A., Ortega, L., Scarabino, F., Maytía, S. \& Demicheli, A. 2006: Mass stranding of Argonauta nodosa Lifhtfoot, 1786 (Cephalopoda, Argonautidae) along the Uruguayan coast (Southwestern Atlantic). Revista de Biología Marina y Oceanografía 41, 147-153.

Digregorio, J.H., Gulisano, C.A., Gutierrez Pleimling, A.R. \& Minniti, S.A. 1984: Esquema de la evolución geodinámica de la Cuenca Neuquina y sus implicancias paleogeográficas. Actas del IX Congreso Geológico Argentino 2, 147-162. San Carlos de Bariloche.

Donovan, S.K. 1989: Taphonomic significance of the encrustation of the dead shell of Recent Spirula spirula (Linné) (Cephalopoda: Coleoidea) by Lepas anatifera Linné (Cirripedia: Thoracia). Journal of Paleontology 63, 698-702.

Doyle, P. \& MacDonald, I.M. 1993: Belemnite battlefields. Lethaia 26, 65-80.

Fernández-López, S.R. 1984: Criterios elementales de reelaboración tafonómica en amonites de la Cordillera Ibérica. Acta Geológica Hispánica 19, 105-116.

Fernández-López, S.R. 1997: Ammonites, clinos tafonómicos y ambientes sedimentarios. Revista Española de Paleontología 12, $102-128$.

Fernández-López, S.R. 2000: Temas de Tafonomía, 167 pp. Departamento de Paleontología, Universidad Complutense de Madrid, Madrid.

Flügel, E. 2004: Microfacies of Carbonate Rocks. Analysis, Interpretation and Application, 976 pp. Springer-Verlag, Berlin-Heidelberg.

Folk, R.L., Andrews, P.B. \& Lewis, D.W. 1970: Detrital sedimentary rock classification and nomenclature for use in New Zealand. New Zealand Journal of Geology and Geophysics 13, 937-968.
Graso, F.W. \& Basil, J.A. 2009: The evolution of flexible behavioral repertoires in cephalopod molluscs. Brain, Behavior and Evolution 74, 231-245.

Groeber, P. 1946: Observaciones Geológicas a lo largo del Meridiano 70. I, Hoja Chos Malal. Revista de la Asociación Geológica Argentina 1, 177-208.

Hewitt, R.A. 1989: Outline of research on the ecology and evolution of the Eocene nautilid cephalopod from the London Clay, England. Tertiary Research 10, 65-81.

Holland, C.H. 1979: Early Cephalopoda. In House, M.R. (ed.): The Origin of Major Invertebrate Groups, 367-379. Academic Press, London.

Holland, C.H., Gnoli, M. \& Histon, K. 1994: Concentrations of Palaeozoic nautiloid cephalopods. Bollettino della Società Paleontologica Italiana 33, 83-99.

Kulicki, C. 1979: The ammonite shell: Its structure, development and biological significance. Acta Palaeontologica Polonica 39, 97142.

Kulicki, C. \& Doguzhaeva, L.A. 1994: Development and calcification of the ammonitella shell. Acta Palaeontologica Polonica 39, $17-44$.

Kummel, B. 1956: Post-Triassic nautiloid genera. Bulletin of Museum of Comparative Zoology at Harvard College 114, 324494.

Ladd, H.S. (ed.) 1957: Treatise on marine ecology and paleoecology. 2, Palaeoecology. Geological Society of America, Memoir 67, $1-1077$.

Landman, N.H., Saunders, W.B., Winston, J.E. \& Harries, P.J. 1987: Incidence and kinds of epizoans on the shells of living Nautilus. In Saunders, W.B., Landman, N.H. (eds): Nautilus: the Biology and Paleobiology of a Living Fossil, 163-177. Plenum, New York.

Landman, N.H., Cochran, J.K., Rye, D.M., Tanabe, K. \& Arnold, J.M. 1994: Early life history of Nautilus: evidence from isotopic analyses of aquarium-reared specimens. Paleobiology 20, 40-51.

Lazo, D.G. 2007: Análisis de biofacies y cambios relativos del nivel del mar en el Miembro Pilmatué de la Formación Agrio, Cretácico Inferior de cuenca Neuquina, Argentina. Ameghiniana 44, 73-89.

Lazo, D.G., Cichowolski, M., Rodríguez, D.L. \& Aguirre-Urreta, M.B. 2005: Lithofacies, palaeocology and palaeoenvironments of the Agrio Formation, Lower Cretaceous of the Neuquén Basin, Argentina. In Veiga, G.D., Spalletti, L.A., Howell, J.A., Schwarz, E. (eds): The Neuquén Basin, Argentina: A Case Study in Sequence Stratigraphy and Basin Dynamics. Geological Society of London, Special Publications 252, 295-315, London.

Lazo, D.G., Aguirre-Urreta, M.B., Price, G.D., Rawson, P.F., Ruffell, A.H. \& Ogle, N. 2008: Palaeosalinity variations in the Early Cretaceous of the Neuquén Basin, Argentina: evidence from oxygen isotopes and palaeoecological analysis. Palaeogeography, Palaeoclimatology, Palaeoecology 260, 477-493.

Leanza, H.A., Hugo, C.A. \& Repol, D. 2001: Hoja Geológica 3969-I, Zapala. Provincia del Neuquén, 128 pp. Instituto de Geología y Recursos Minerales, Servicio Geológico Minero Argentino, Boletín 275.

Legarreta, L. \& Gulisano, C.A. 1989: Análisis estratigráfico secuencial de la Cuenca Neuquina (Triásico Superior-Terciario Inferior). In Chebli G.A., Spalletti L.A. (eds): Cuencas Sedimentarias Argentinas, 221-243. Correlación Geológica 6, Universidad Nacional de Tucumán, Tucumán

Lukeneder, A. 2005: Taphonomy and stratigraphy of Early Cretaceous ammonoid mass occurrences (Late Valanginian; Northern Calcareous Alps, Upper Austria). Austrian Journal of Earth Sciences $98,34-51$.

Lukeneder, A. \& Harzhauser, M. 2002: Shell Accumulations of the Nautilidae Aturia (Aturia) aturi in the Lower Miocene Paratethys. In Summesberger, H., Histon, K., Daurer, A. (eds): Cephalopods - Present and Past. Abhandlungen der Geologischen Bundesanstalt 57, 459-466, Wien.

Lukeneder, A. \& Harzhauser, M. 2003: Olcostephanus guebhardi as cryptic habitat for an Early Cretaceous coelobite community (Valanginian, Northern Calcareous Alps, Austria). Cretaceous Research 24, 477-485. 
Lukeneder, A., Harzhauser, M., Mandic, O. \& Roetzel, R. 1999: Shell accumulation of the Nautilidae Aturia (Aturia) aturi (Basterot, 1825) in the Retz-Formation (Lower Austria, Upper Eggenburgian, Lower Miocene). Abstracts. V International Symposium. Cephalopods - Present and Past, 76. Vienna.

Lukeneder, A., Harzhauser, M., Müllegger, S. \& Piller, W.E. 2008: Stable isotopes $\left(\delta^{18} \mathrm{O}\right.$ and $\left.\delta^{13} \mathrm{C}\right)$ in Spirula spirula shells from three major oceans indicate developmental changes paralleling depth distributions. Marine Biology 154, 175-182.

Maeda, H., Mapes, R.H. \& Mapes, G. 2003: Taphonomic features of a Lower Permian beached cephalopod assemblage from Central Texas. Palaios 18, 421-434.

Mapes, R.H., Hembree, D.I., Rasor, B.A., Stigall, A., Goirand, C. \& Richer De Forges, B. 2010a: Modern Nautilus (Cephalopoda) taphonomy in a subtidal to backshore environment, Lifou (Loyalty Islands). Palaios 25, 656-670.

Mapes, R.H., Landman, N.H., Cochran, K., Goiran, C., Richer De Forges, B. \& Renfro, A. 2010b: Early taphonomy and significance of naturally submerged Nautilus shells from the New Caledonia Region. Palaios 25, 597-610.

Matsushima, Y. 1990: Nautilus pompilius drifts on the northeast coast of Sumba Island, Indonesia. Bulletin of the Kanagawa Prefectural Museum (Natural Science) 19, 33-43. [in Japanese with English abstract]

Moore, E.J. 1984: Molluscan paleontology and biostratigraphy of the Lower Miocene Upper Part of the Lincoln Creek Formation in southwestern Washington. Contributions in Science Natural History Museum of Los Angeles County 351, 1-39.

Mount, J.F. 1984: Mixing of siliclastic and carbonate sediments in shallow shelf environments. Geology 12, 432-435.

Müller, A.H. 1979: Fossilization (taphonomy). In Robinson R.A., Teichert C. (eds): Treatise on Invertebrate Paleontology, 2-78, Part A. Geological Society of America and University of Kansas Press, Lawrence.

Rawson, P.F. 2000: The response of Cretaceous cephalopods to global change. In Culver, S.J., Rawson, P.F. (eds): Biotic Response to Global Change, 97-106. Cambridge University Press, Cambridge.

Reyment, R.A. 2005: Active migration and passive transport of marine organisms in the fossil record. In Ashraf, M.T.E. (ed.): Migration of Organisms, 7-21. Springer Verlag, Netherlands.

Reyment, R.A. 2008: A review of the post-mortem dispersal of cephalopod shells. Palaeontologia Electronica 11, 12A, 13 pp. <http://palaeo- electronica.org/2008_3/148/index.html>.
Roux, M. 1990: Underwater observations of Nautilus macromphalus off New Caledonia. Chambered Nautilus Newsletter 60, 1.

Saunders, W.B. \& Landman, N.H. (eds) 1987: Nautilus: the Biology and Paleobiology of a Living Fossil, 632 pp. Plenum, New York.

Saunders, W.B. \& Ward, P.D. 1987: Ecology, distribution, and population characteristics of Nautilus. In Saunders, W.B., Landman, N.H. (eds): Nautilus: the Biology and Paleobiology of a Living Fossil, 137-162. Plenum, New York.

Shimansky, V.N. 1975. Cretaceous nautiloids. Academy of Sciences of the USSR, Transactions of the Palaeontological Institute 150, 1-288.[In Russian]

Spalletti, L.A. 1992: Parasecuencias en una plataforma dominada por olas de tormenta, Formación Agrio, Cuenca Neuquina, Argentina. Actas de la IV Reunión Argentina de Sedimentología 1, 33-40.

Strasser, A. 1986: Ooids in Purbeck limestones (lowermost Cretaceous) of Swiss and French Jura. Sedimentology 33, 711-727.

Talavara, F. \& Faustino, A. 1931: Industrial shells of the Philippines. Philippine Journal of Science 3, 321-350.

Veiga, G.D., Spalletti, L.A. \& Flint, S. 2002: Aeolian/fluvial interactions and high-resolution sequence stratigraphy of a nonmarine lowstand wedge: the Avile Member of the Agrio Formation (Lower Cretaceous), central Neuquén Basin, Argentina. Sedimentology 49, 1001-1019.

Wani, R. 2004: Experimental fragmentation patterns of modern Nautilus shells and the implications for fossil cephalopod taphonomy. Lethaia 37, 113-123.

Wani, R. 2007: How to recognize in situ fossil cephalopods: Evidence from experiments with modern Nautilus. Lethaia 40, 305311.

Wani, R., Kase, T., Shigeta, Y. \& De Ocampo, R. 2005: New look at ammonoid taphonomy, based on field experiments with modern chambered nautilus. Geology 33, 849-852.

Weaver, C.E. 1931: Paleontology of the Jurassic and Cretaceous of West Central Argentina. Memoirs of the University of Washington $1,1-469$.

Westermann, G.E.G. 1973: Strength of concave septa and depth limits of fossil cephalopods. Lethaia 6, 383-403.

Westermann, G.G.E. 1999: Life habits of nautiloids. In Savazzi, E. (ed.), The Functional Morphology of the Invertebrate Skeleton, 263-298. John Willey and Sons, Chichester.

Zinsmeister, W.J. 1987: Unusual nautilid occurrence in the Upper Eocene La Meseta Formation, Seymour Island, Antarctica. Journal of Paleontology 61, 724-726. 